\title{
VIDÉKKUTATÁS ELŐZMÉNYEKKEL ÉS TÉNYEKKEL
}

\author{
(Research of Rural Areas with Preliminaries and Facts)
}

SZÖRÉNYINÉ KUKORELLI IRÉN

Kulcsszavak:

vidékfejlesttés kistérségek SAPARD területfejles=tés

$A=$ intézet tizenöt éves fennállása óta a területi folyamatok vizsgálatában meghatáro=ó jelentôséggel birt a falusi terek kutatása. Az elmúlt tizenöt év során a vidéki terek kutatását illetổen intézetünk az alábbi föbb kérdésekre koncentrált:

- A perifériális területeket, vidéki térségeket vajon hogyan érintette a rendszerváltással elinduló folyamat, és ezzel egy idöben milyen hatást gyakorolt rájuk a hozaank mindinkább közelebb kerülö Európai Unió terület- és vidékfejlesztési politikája?

- A területfejlesztés új eszközrendszerének a kialakitás, és az újonnan kialakuló intézményrendszer mennyiben járult hozzá a falusi terek átstrukturálódásához, avagy mennyiben differenciálódott nálunk a vidék, sez vajon megnyilvánult-e a funkcióváltásban is?

A térszerkezeti struktúrák változása, a kistérségi szint kialakulása és mũködőképessége, valamint a vidéki gazdaság és jövedelemteremtést magában foglaló kutatások eredményeinek öss=efoglalója a fenti kérdésekre ad válas=t.

Tizenöt évvel ezelőtt, mint minden új kutatóintézetben, a munkatársak, a kutatók keresték azokat a kutatási témaköröket, melyek az intézet profilját és az elkövetkezendő évtized munkásságát megalapozhatják. A fö témakör - az anyaintézet profiljából adódóan -, a területi folyamatok vizsgálata lett, de ezen belül a város-vidék, a centrum-periféria kapcsolatának elemzése kitüntetett jelentőséggel bírt. Másik részről az intézet létrehozásában bábáskodó, az intézetet pénzügyileg támogató Györ-Moson-Sopron Megyei Tanács is arra inspirált bennünket, hogy a megye azon területeivel is foglalkozzunk, melyek nem csak földrajzilag, hanem a társadalmi kutatások tekintetében is perifériára szorultak a korábbi évtizedekben. Így került sor az intézet valamennyi munkatársának bevonásával végzett elsö empirikus kutatásra, az ủn. Rábaköz kutatásra, amelynek eredményeit intézetünk első könyveként publikáltuk (Rechnitzer 1988). EZt a munkát tekinthetjük az első kistérségi kutatásnak, annak ellenére, hogy akkortájt a kistérség mint fogalom még nem definiálódott.

Intézetünk a területi folyamatok komplex megközelítését állította a kutatások középpontjába, ezért már a rendszerváltozást megelözöen megkülönböztetett figyelemmel kísérte a különbözỏ típusú tereket, úm. a centrum térségek, válságterületek, határ menti területek, perifériák. Ezeknek a területeknek a kezelése még a centralizált hatalmi struktúrában is egyedi elbírálást, a területi specifikumok figyelembe vételét kívánta meg. Mondhatjuk tehát, hogy intézetünk a rendszerváltásra már a kilencvenes évek elött felkészült azzal, hogy a területi specifikumok vizsgálatára és annak komplex elemzésére irányította a kutatók figyelmét. 
A rendszerváltó folyamatok a városokban, a centrumtérségekben elöbb és erőteljesebben érvényesültek, mint a perifériális területeken, a vidéki, elmaradott térségekben. A rendszerváltást követően divatosabb és látványosabb volt a centrum térségek, az innovációs zónák, mint a leszakadó, hátrányos térségek vizsgálata. Mégis, mivel a kutatónak a feladata a problémák objektív kezelése és bemutatása, így a területi folyamatok vizsgálatát a reflektorfénybe nem került vidéki tereken is folytattuk. Intézetünknek és benne a falusi terekkel foglalkozó kutatóknak is az az álláspontja, hogy a vidékkutatás szerves része a regionális tudománynak, tehát csak vele együtt valósulhat meg a regionális kutatás komplexitása.

Az elmúlt tizenöt év során a vidéki terek kutatását illetően intézetünk az alábbi fóbb kérdésekre koncentrált:

- A perifériális területeket, vidéki térségeket vajon hogyan érintette a rendszerváltással elinduló folyamat, és ezzel egyidőben milyen hatást gyakorolt rájuk a hozzánk mindinkább közelebb kerülő Európai Unió területés vidékfejlesztési politikája?

- A területfejlesztés új eszközrendszerének a kialakítása és az újonnan kialakuló intézményrendszer mennyiben járult hozzá a falusi terek átstrukturálódásához, avagy mennyiben differenciálódott nálunk a vidék, s ez vajon megnyilvánult-e a funkcióváltásban is?

A válaszadáshoz számos kutatási program segítségével jutottunk el. Az OTKA, OKTK és OFA kutatások mellett a korábbi KTM, a mai FVM és számos kistérségi társulás is megbízott bennünket azzal, hogy az empirikus kutatásokon keresztül az elméleti és gyakorlati kérdések ne maradjanak megválaszolatlanul.

A vidéki területeket a rendszerváltást követöen számos erős sokkhatás érte az ország magterületeihez, nagyvárosaihoz képest. Ezekböl a továbbiakban csupán felvillantásra kerül néhány elem.

- A kilencvenes évek elejétöl a szövetkezeti törvény és a kárpótlási törvény, majd az azt követỏ kárpótlási folyamat következtében az addigi tulajdonviszonyok és gazdálkodási formák (a mezögazdasági termelöszövetkezetek) felbomlottak, miközben az ország addigi agrárpiacai eröteljesen beszűkültek, a mezögazdasági termelés mennyisége jelentős mértékben csökkent.

- A mezőgazdasági termelőszövetkezetek falu menedzselő szerepe megszünt, ezzel a falvakban az addigi TSZ által elvégzett "társadalmi munka” elvégzetlen maradt, hiszen az önkormányzatok részben felkészületlenségböl, részben pénz- és eszközhiányból fakadóan nem tudták ellátni az ilyen irányú feladataikat. De a helyi társadalmi, civil szervezetek is sok esetben mủködésképtelenekké váltak a szponzori szerep megszüntével.

- A szövetkezeteknek a felbomlásuk, illetve az újjáalakulásuk során megszünt a korábbi foglalkoztató funkciója, ami elsősorban a létszám leépítésben tükröződött, ezzel a helyben foglalkoztatottak váltak munkanélkülivé, megjelent a falusi munkanélküliség.

- A falusi munkanélküliség másik összetevőjét a helyben és a közeli városokban dolgozó ipari foglalkoztatottak leépítése jelentette. A TSZ melléküzemágak és 
a telephelyi ipar volt a legsérülékenyebb az ipari szerkezetváltás során, így ezek összeomlása és felszámolása szintén a falusi munkanélküliséget növelte.

Mind az Európai Unióban, mind Magyarországon sokat hallhatunk a vidék fogalmáról, söt itthon, az elmúlt évtizedben több tudományos vita folyt magáról a definíciójáról is. A vidék általános definíciója mögött látnunk kell viszont azokat a differenciákat, amelyek mind Magyarország, mind az EU országainak vidéki térségeire jellemzőek. Az EU megkülönbözteti a döntő mértékben vidéki, jelentős mértékben vidéki és a döntö mértékben városias területeket. Nálunk a hasonló kategorizáláson túl érdemes az elmúlt évtizedben folyó változások hatására a mikrotereket tipizálni, $\mathrm{s}$ ezek segítségével rámutatni azokra a térszerkezeti változásokra, amelyek a társadalmi, gazdasági rendszerváltást követően bontakoztak ki.

\section{A differenciált vidék, avagy az átalakuló vidéki gazdaság}

Az országos folyamatokra a különbözö vidéki terek különbözöképpen reagálnak, de arra, hogy a válságszituációkat csak túlélték, vagy sikerült azt az előnyükre fordítani, csak a kutatások tudnak választ adni. Erre egy sokváltozós társadalmi és gazdasági elemzés segítségével kaphattunk választ, melyet kistérségi szinten végeztünk el. A vizsgálatainkban általában, és ebben is, nem a KSH kistérségi szintet tekintettük vizsgálati szintnek, hanem a kistérségi szerveződések területi szintjét. E kistérségi szint lehatárolásánál a tájtudatot, a már meglévő kistérségi szerveződéseket éppen úgy figyelembe vettük, mint a városok körül kialakult, s létező vonzáskörzeteket. A kutatás során - de mondhatjuk, hogy a tizenöt év során - legtöbb esetben empíriaként a megye vagy a régió szolgált.

Bár a kilencvenes évtized már nem a matematikai modellek évtizede volt, mi mégis a faktor- és klaszteranalízis segítségével elemeztük a kistérségi szinten megmutatkozó térségi differenciákat. A vizsgálat segítségével Észak-Dunántúl gazdasági és térszerkezeti változásaira mutattunk rá. A mintegy harminc mutatóval közelített módszerrel a szintetizálás fázisában definiálásra kerültek a kistérségi típusok, melyek a következök:

1. Rurális térségek jó humán tókével és jó infrastruktúrával:

példaként: Szigetköz, Sokoró, Fertö-mente, csornai kistérség

2. Depressziós rurális térségek (kedvezőtlen humántőke állomány, rossz infrastruktúra ellátottság):

példaként: Kavicstakaró, Dél-Rábaköz, Somló-környék, Balatonfelvidék, Göcsej-Örség-Hetés, ZalaKar

3. Egyéb rurális térségek:

3/A. Egyéb rurális térség jó humán eröforrással, kedvezötlen infrastruktúra ellátottsággal: példaként: Mosoni-sík, Tóköz, Muramente, Öriszentpéter kistérsége 
Szörényiné Kukorelli Irén: Vidékkutatás elözményekkel és tényekkel.

Tér és Társadalom, 15. 2001. 2. 71-85. p.

74 Szörényiné Kukorelli Irén

TÉT XV. évf. 2001

3/B. Egyéb rurális térség kedvezötlen humán eröforrással, jó infrastruktúra ellátottsággal:

példaként: Alpokalja, Kis-Balaton, Csepreg-Bük

4. Gazdasági innováció pólusterületei (a legjobb gazdasági aktivitáshoz jó

humántőke és kiépített infrastruktúra párosul)

példaként: Sopron, Győr, Szombathely, Veszprém, Kapuvár,

Mosonmagyaróvár, Köszeg, Zalaegerszeg városok és térségeik

5. Vegyes gazdaságú térségek

5/A. Vegyes gazdaságú térségek közepes vagy annál gyengébb gazdasági

aktivitással, kedvezö humán eröforrással, rossz infrastruktúra

ellátottsággal:

példaként: Körmend, Pápa, Tapolca, Ajka, Várpalota, Répcelak, Jánosháza települések és kistérségeik

5/B. Vegyes gazdaságú térségek, közepes vagy annál gyengébb gazdasági

aktivitással, kedvezötlen humán eröforrással, de jó infrastruktúrával:

példaként: Sokoróalja, Sárvár, Zalaszentgrót, Zalalövő kistérségei

6. Depressziós vegyes gazdaságú térségek, amelyeket a kedvezötlen humán töke és az infrastruktúra alacsony szintje jellemez:

példaként: Celldömölk, Zirc, Letenye, Sümeg, Vasvár, Szentgotthárd,

Nagykanizsa, Zalaszántó települések és kistérségeik, valamint a

Kerkamente és Belső-Göcsej

7. Turizmus által frekventált területek magas szintü gazdasági, vállalkozási

aktivitással, jó humán tỏkével és kedvezö infrastruktúrával:

példaként: Balaton mente, Keszthely-Hévíz térsége

$\mathrm{Az}$ egyes kistérségek típusaihoz rendelt pontértékek alapján a vizsgált terület térszerkezetében a fejlett térségek három különbözö sávját lehet elkülöníteni:

I. Északnyugat-délkeleti irányú északi sáv,

2. Nyugati határmenti sáv,

3. A régió déli pereme - Balaton mente.

A fejlettséget hordozó térségek mellett élesen lehatárolhatóvá vált a terület ún. "depressziós teknó" -je is, mely Vas, Veszprém és Zala megye közös megyehatár menti térségeit foglalja magába.

A határ menti területek voltak azok a területek, amelyek a korábbi hátrányukat le tudták küzdeni, s fekvésükböl adódóan a korábbi hátrányos helyzetüket elönnyé tudták változtatni, különösen ami a gazdasági faktorokat illeti. Sajátságos a déli perem, azaz a Balaton menti sáv jellemzője, ez az a terület, amely kiugrik a vállalkozói aktivitásával és kedvező infrastrukturájával, míg a Balaton háttértelepüléseinek mikrotere a depressziós típusba tartozik.

A különböző, egymástól jól elkülöníthető innovációs és depressziós térségek mellett külön figyelmet érdemelnek azok a térségek, melyeket az ún. vegyes 
gazdaságú térség kategóriába soroltunk. Ezek azok a területek, melyek nem kellö odafigyelés esetén visszacsúszhatnak a depressziós kategóriába, különösen a gyenge humán tỏkéjük miatt (Szörényiné Kukorelli 1997b).

A vizsgálat eredménye rámutatott arra, hogy mikrotérségi szinten a területi differenciák sokkal valóságosabb képet képesek mutatni, s így azok kezeléséhez is ilyen szintủ vizsgálatokra van szükség.

A kilencvenes évek második felében intézetünk kutatócsoportjai foglalkoztak a vidéki térségek jövedelemtermelö képességével (Lados 2000), ehhez a helyi adó potenciál, a központi támogatásoktól való függőség, az adósságszolgálati ráta, a tartalék szint és a mủködési bevételek terheltsége, valamint az átlagos felhalmozási ráta mutatók segítségével kistérségi szinten került elemzésre a jövedelemtermelési képesség, megalkotásra került az önkormányzatok egyik finanszírozási modellje.

Mivel a helyi adópotenciál legnagyobb hányadát az iparüzési adó szolgáltatja (85\%), ezért ennek az adófajtának a települések és kistérségek egyenlötlenségében óriási szerepe van. Ebben a témakörben tett vizsgálataink rámutattak arra, hogy a kistérségek financiális problémáinak és mủködőképességük megőrzésének egyik lehetséges megoldásaként szolgálhatna a kistérségi szintű iparủzési adó elterjesztése. A számítások országos szinten KSH kistérségekre készültek, települési, kistérségi és természetesen megyei és regionális szintre is összegezve. A megyénkénti és a régiónkénti egy före jutó átlagok is bizonyítják azt, hogy ennek az adófajtának a mennyisége jól tükrözi a területi különbségeket, hiszen első helyen a központi régió, második helyen a Közép-dunántúli régió, s harmadik helyen a Nyugat-dunántúli régió áll, míg az Észak-Alfơld az országos átlag felét sem éri el.

A kistérségi iparủzési adó bevezetése esetén az az egyik fó kérdés, hogy egy kistérségen belül hány településen van, $s$ hány településen nincs iparüzési adó, hiszen ez lehet az egyik legnagyobb konfliktusforrás.

A megállapított típusok a következők:

- erösen differenciált kistérség, ahol a települések 10\%-ánál vagy annál kevesebbnél van iparúzési ado;

- kvázi differenciált kistérség: a települések 11-35\%-ában van iparüzési adó;

- megosztott kistérségek: a települések 36-65\%-ában van iparüzési adó;

- kvázi homogén kistérségek: a települések 66-90\%-ában van iparüzési adó;

- homogén kistérségek: a települések 91\%-ában, vagy annál többnél van iparüzési adó.

A kutatási téma kidolgozása során a következő megállapításokra jutottunk: az iparüzési adó kistérségi szinten való terítése esetén, és annak térségfejlesztési társuláshoz való juttatásával a társulás helyi forrásának képzése megtörténhetne, s egyben növelné a kistérség kohézióját, valamint:

- az iparüzési adó kistérségen belüli erős differenciáló jellege megszúnne, mert:

- ma a kistérségen belül érdekellentéteket szít és versenyt indít el, hogy valamely befektető melyik települést választja. Ha sikerül egy térségnek megszerezni a befektetőt, akkor már másodlagossá válna, hogy mely települést választja telephelyül - a kistérségi koncepció prioritásai is jobban érvé- 
nyesülhetnének, hiszen ma a települési és kistérségi érdek ebböl a szempontból különbözö. Példaként említhetnénk, hogy van egy település, mely a térség gazdasági központja, infrastruktúrával ellátott, kialakított iparterülettel rendelkezik, míg a szomszédos aprófalu a falusi turizmust preferálja, de ha mégis ide települne az adott üzem, több haszna lenne a kistelepülésnek belöle,

- a térségfejlesztés a térségen belüli érdekellentéteken nem alapulhat, ez a rendszer az érdekellentétek elsimítása felé hatna hosszú távon,

- ezen adófajta bevezetése még inkább a kistérségi gazdasági háló kialakulását segítené, például a térségi beszállítói kör és a foglalkoztatottak miatt,

- nem lenne az önkormányzatok részéröl az a kényszer, miszerint „,csak valami ipari üzem jöjjön ide, mindegy, hogy milyen" - azaz az ésszerütlen telephely kialakítást megakadályozná.

A fent felsoroltak bevezetésére is több alternatívát javasoltunk (Szörényiné Kukorelli 1999d; 2000a).

A vidék differenciálódására utalnak a vidéki gazdasággal foglalkozó kutatási témák további eredményei is, melyek egyértelmüen bebizonyították, hogy a vidéki terek közül az innovációs zónához és a nyugati határ menti sávhoz tartozó települések gazdasági, vállalkozási aktivitása erös, sok esetben azonos a városok vállalkozás aktivitási rátájával. Példaként említhető, hogy míg a soproni kistérség ezer före jutó müködő vállalkozásainak száma 78 , addig a Tét-Pannonhalma kistérségben ugyanez az étték 47,8, a Győr-Moson-Sopron megye falusi átlaga 52,3 .

Az osztrák határ menti vidéki területek társadalmi-gazdasági arculatát a határ nyitottá válása megváltoztatta. Megélénkült és átalakult a gazdaság, mely megváltoztatta a térség arculatát, és felértékelte a térséget az itt lakók és ide költözők számára.

A kedvezőbb gazdasági miliö, a magasabb jövedelmi szint, az életminőség javulása az alábbi tényezőknek köszönhető, amint azt „A regionális differenciák a vidéki Magyarországon" közös magyar-amerikai kutatás is alátámasztotta (Szörényiné Kukorelli 2000c):

- magasabb jövedelmek (a legális vagy illegális munkavállalás Ausztriában átlagosan a hazai jövedelmek 8-15-szörösét biztosítja);

- más rurális térségeknél kisebb valódi munkanélküliség a külföldi munkavállalás (szakmunkák, segédmunkák, mezőgazdasági szezonális munkavállalás) lehetősége miatt;

- bármely turisztikai céllal megjelenö vendégek Ausztriából - növekvö keresletet indukál az országosnál magasabb árszínvonalon;

- turizmus adottságain alapuló fejlesztés lehetösége

- Fertỏ tó - osztrák oldalon már müködỏ turizmussal,

- Fertö-Hanság Nemzeti Park - alakuló ökoturizmus,

- kerékpárútvonalak építése (Fertő menti kerékpárút, szigetközi kerékpárút);

- a nyugati gazdasági és társadalmi modellek megismerése; 
- a nyugati fogyasztási szokások elterjedése;

- rokoni-baráti kapcsolatok újjáéledése, újak kiépülése;

- új üzleti kapcsolatok kiépülése.

A fenti tényezők hozzájárultak a térség felértékelődéséhez. A gazdaság az ország belső területeinél kedvezöbb helyzetbe került, az itt élő lakosság jövedelme az országos falusi átlagnál gyorsabban növekedett.

A határ menti sávtól az ország belseje felé húzódó vidéki terek csak akkor lesznek képesek hasonló megújulásra, ha a határ menti területek gazdasági folyamatai az ország belseje felé képesek tovább diffundálni, s ott a helyi lakosság adaptív képességével találkoznak.

\section{Térszerkezet vizsgálata térkapcsolat-analizis módszerével}

Intézetünkben a vidéki terek kutatásának másik fó vonulata a térszerkezeti vizsgálatok voltak a lakossági térkapcsolat-analízis segítségével.

A társadalmi-gazdasági átalakulás során megváltoztak a lakosság mozgásirányai, a kötelezően, adminisztratívan leszabályozott igénybevehető szolgáltatások fellazultak, az egészségügyi, oktatási irányokat a kínálat-kereslet, a szabad választás határozhatja meg. A már nem csak nagyvárosokban épülỏ bevásárlóközpontok, vagy az új kereskedelmi vállalkozások miatt a kereskedelmi térpályák módosulnak, de éppen a piacgazdasággal fưgg össze az újonnan kialakuló pénzügyi, üzleti szolgáltatások igénybevétele, lakossági térpályáinak kialakulása is. A szabadidő kapcsolatok irányai is átrendezödtek, a nemzetközi kapcsolatok pedig a falusi térségekben valójában a kilencvenes évek után hódítottak teret.

A térkapcsolat-analízis módszerével a lakossági és a településkérdőív segítségével vâlaszt kapunk a vizsgált térség kapcsolati rendszerére, a központok valóságos vagy vélt szerepére, s lehatárolhatjuk azt a földrajzi teret, amelyen belül a kapcsolatok sürübbek, többségben az adott téren belül mutatnak, $s$ ennek alapján kirajzolható a kistérség határa is.

A lakossági térkapcsolatok átrendeződése a falusi terek térszerkezetében idézett elő jelentős változást, új csomópontok keletkeztek átlépve a korábbi berögzült közigazgatással összefüggő zártnak tünő tereket. A térpálya kapcsolatokra vonatkozó kérdőíves felmérések és feldolgozásuk lehetőséget teremtett a lakossági mozgáspályákon alapuló kistérségi lehatárolás megteremtésére. A módszer továbbá választ ad a térség és a telepưlései zártságára, a települések kohéziójára és centralizációjára a településre mutató, a településből kifelé mutató, s magára a településre önmagára mutató térpályák összefüggései alapján.

A kistérség lehatárolása nem egy egyszerủ feladat, hiszen sem a közigazgatási, sem a természetföldrajzi határok kizárólagosan nem definiálhatják, sokkal komplexebb területi egységről van szó, olyanról, ahol egy településkör történelmi, kulturális gyökereit, társadalmi-gazdasági adottságait, néprajzi értékeit együttesen kell vizsgálni, és azt az összetartozó területet, ahol ezen tényezők homogenitása a legnagyobb, nevezhetjük kistérségnek (Rechnitzer-Szörényiné Kukorelli 1994). A 
térkapcsolat-analízis módszere ehhez nyújtott segítséget, s így sikerült GyörMoson-Sopron megye egészére egy kistérségi lehatárolásra javaslatot tenni, s ezáltal az alulról szerveződő kistérségi társulások megalakítására, földrajzi terének kialakítására is javaslattal élni. Györ-Moson-Sopron megye önkormányzata elfogadta a térkapcsolat-analízis módszerével lehatárolt mikrotér beosztást, $\mathrm{s}$ erre a térfelosztásra készítette el intézkedéseit a megyei területfejlesztési koncepcióban. A másik eredmény, hogy a tizennégy kistérség lehatárolása megelözte a nagy kistérségi szervezödési hullámot, s így mintegy tudományos megalapozottsággal tehettünk javaslatot a kialakítandó mikroterekre. 1998-ig meg is alakultak a megyében ezek a társulások, az azóta megjelenő újabb kistérségi társulások ezeknek az osztódásából jöttek létre (Szörényiné Kukorelli 1998).

A módszer felhasználásra került a Balaton területfejlesztési koncepciójának elkészítése során is.

\section{A vidéki mikrotér kialakulása és szerepe a területfejlesztés folyamatában}

Intézetünk már tizenöt évvel ezelőtt mikrotér vizsgálatokba kezdett, akkor, amikor még a kistérségi vizsgálatok nem váltak a szakma divatjává. A kilencvenes évek területi politikája a kistérségi szintet mint az alulról építkezés szintjét teremtette meg.

$\mathrm{Az}$ intézetben folyó vidékkutatások ennek a szintnek mind a gyakorlati, mind az elméleti kutatásait felvállalták, azaz egyszerre folytatott kutatást a szint definiálására és az intézmény és eszközrendszerének lehetséges megteremtésére, valamint ott volt a gyakorlat oldalán is, mikor a kistérségi szintủ fejlesztéseket megalapozó területfejlesztési koncepciók, majd később a stratégiai vidékfejlesztési programok készítését végezte.

A Magyarországon 1992-ben elinduló PHARE Területfejlesztési Programnak az 1993-tól életbe lépó településközi együttmüködési komponense adott talajt és egyben lendületet a kistérségi szerveződéseknek, miközben közvetítette az Európai Unió vidékfejlesztési politikáját, amely alulról építkezö, azaz a helyi közösségen alapuló integrált vidékfejlesztést tüzte zászlajára. A vidéki térségek adaptív képességét és nyitottságát mi sem bizonyítja jobban, mint az, hogy a szerény, de elérhetö források reményében két éven belül 138, a PHARE programnak eleget tevő kistérségi szerveződés alakult.

Intézetünk felvállalta Győr-Moson-Sopron megye és a Nyugat-dunántúli régió kistérségeivel való szoros kapcsolattartást, s ezen keresztül a kistérségi szint vizsgálatához folyamatosan gyưlt az empíria, mely hozzá tudott járulni az elméleti kutatásokhoz.

Már a fent említett PHARE Településközi Programban is részt vettünk, amikor a Rábcatorok társulás területfejlesztési koncepcióját a program keretében elkészítettük. Hasonlóan az elsők voltunk az OFA keretében meghirdetett területfejlesztési program kidolgozásában, mikor a Muramente Nemzetiségi Területfejlesztési Társulás koncepciójának készítését nyertük el. 
$\mathrm{Az}$ intézetben egyszerre kezdtünk hozzá a különböző területi szintek területfejlesztési dokumentumainak az elkészítéséhez. A kistérségi koncepciók készítésének gyakorlata kapcsán szintetizálásra került a készítés módszertana, e módszertan alapján került kidolgozásra Györ-Moson-Sopron megye hét kistérségének területfejlesztési koncepciója. A kistérségi koncepció már a léptéke miatt is jelentős különbségeket hordoz a megyére vagy régióra vonatkozó területfejlesztési koncepcióval szemben. A felhasználói és az érintett kör miatt viszont lényegesen részletesebb kidolgozást igényel, és sokkal inkább a helyi közösségekre támaszkodik, nemcsak az önkormányzatok bevonására kell gondolni, hanem a térségben élö vállalkozóknak, civil szervezeteknek a véleményét is ki kell kérni. Ezért érthetö, hogy a kistérségi szintủ vidékfejlesztés alapvetö elvărása a helyi közösségek bevonása, azaz a helyi szerepelőkkel való együttmúködés a koncepció későbbi használhatósága érdekében. Ezt a folyamatot mi is tanultuk a kilencvenes évek első felében, de ez a gyakorlati megközelítés éppúgy hozzátartozik a mikroterek kezeléséhez, mint az endogén erőforrások feltárása és elemzése.

A kistérségi koncepció módszerére vonatkozóan négy alapvető ismérvet kell kiemelni, ami lényegesen különbözik a nagyobb téregységre készüló fejlesztési stratégiáktól:

- településszintre való építkezés fontossága;

- helyi szereplök folyamatos közremüködése a koncepciókészítés során, azaz a közös tervezési módszer;

- a koncepció megfogalmazásán túl a programok részletes kimunkálása;

- a folyamatos társadalmi kontroll.

A kistérségi koncepció használhatóságának néhány momentumát kell kiemelnünk:

- a nagyobb téregység (megye, régió) területfejlesztési koncepciójához való illesztés fontosságát;

- a szomszédos kistérségek koncepcióival való egyeztetés, összehangolás;

- módosításának lehetősége, szükségessége, flexibilitása;

- alkalmasságuk a rendezési tervek elökészítésére.

Az elmúlt tíz év kistérségi szintủ programkészítési gyakorlata azt mutatta, hogy a kistérségi stratégiának egyszerre kell megfelelnie a helyi, a térségi szereplök felé, alkalmazkodnia kell a szomszédos kistérségek koncepcióihoz, kapcsolódnia kell a megyei fejlesztési stratégiához, és el kell tudni magát fogadtatnia a felhasználókkal, befektetőkkel is (Szörényiné Kukorelli 1997a), de mindemellett nem szabad elfelejteni, hogy a térségfejlesztés alapvető célja az adott területen élő népesség életminőségének javítása.

Egy fontos kritérium a kistérségi program készités, illetve müködés során a civil szervezetek bevonása, mely sajnos a fontossága ellenére nem müködik jól. Az FVM megbízásából készült kutatás arra mutatott rá, hogy a civil szervezetek és a kistérségi társulások kapcsolata gyenge, $\mathrm{s}$ főleg kiépítetlen még a kistérségi szintü civil szervezeti struktúra (Szörényiné Kukorelli 1999c). 
Szörényiné Kukorelli Irén: Vidékkutatás előzményekkel és tényekkel.

Tér és Társadalom, 15. 2001. 2. 71-85. p.

- A törvényben elöírt Önkormányzati területfejlesztési társulási forma nem kedvez a civil szervezetekkel való partnerségi viszony szorosabbá tételének azzal, hogy a civil szervezeteknek a társulásban tagként való részvétele nem megengedett.

- Tény, hogy a falusi térségekben is aktivizálódott a helyi társadalom, de a társulásokkal kiépített partnerségi viszony gyenge.

- A társulásoknak általában nincs szerepük a müködésük ideje alatt megalakuló civil szervezetek létrehozásában, azaz nem töltenek be katalizátor szerepet, $\mathrm{s}$ ez ugyancsak alátámasztja az együttmüködés hiányát.

- Kevés a társulások földrajzi területére kiterjedỏ civil szervezet, müködési területük inkább településhatáros, mint térséghatáros.

- A kistérségi társulásoknak a nemzetközi, az országos, a regionális és megyei civil szervezetekkel való partnerségi viszonya gyenge.

A munka nehézségét, de egyben a szépségét is sok esetben nem a kutatómunka, hanem a visszacsatolások sorozata teszi még izgalmasabbá és használhatóvá. Intézetünk a fent említett kistérségi programok által a koncepció és programkészítés fázisainak mind a gyakorlati, mind az elméleti oldalát megtanulta.

\section{Az intézményesülő mikroterek kialakulási folyamata és szerepük az EU konform vidékfejlesztésben}

A kistérségi koncepciók készítése mellett az intézet kutatási témáiban fontos szerepet kapott a kistérségi szint vizsgálata, annak működőképessége, intézményesülésének lehetősége. A múködőképesség vizsgálatára országos szinten több kutatási program keretében került sor (OFA 1999; FVM 2000.), s ennek tapasztalatait, kutatási eredményeit a következökben foglaljuk össze.

A kistérségi szint egy olyan területi szint, mely magyarországi, sőt európai uniós minta és tapasztalat nélkül formálódott, és a források hiányának ellenére megmaradt. Megmaradását, müködését, kialakult státuszát az alulról építkezésben kell keresni, ereje a helyi döntéshozók tenni akarásában lelhetó fel. $A z$ együttmüködések életre hivása, születésük elömozditója legtöbbször valamely pályázati lehetöség, illetve pályázati lehetöség feltétele volt. Ezek az okok kampányszerü megalakulásukkal nyomon követhetök (Szörényiné Kukorelli 2000b).

$\mathrm{Az}$ indítékot elsösorban a külső források megszerzése jelentette, mint például a pályázati támogatások (OFA, PHARE), melyek elnyerését létező kistérségi szerveződések, településszövetségek számára tették csak lehetővé. $\mathrm{Az}$ önkormányzatok döntéshozói éppen a szükülő helyi források miatt hamar felismerték a társulásban rejlö forrásszerzési lehetőséget, így a belsö indíttatás mellett erösebben dominált a külsố tényezö, amely a települések alulról építkező integrálódásához vezetett.

A kutatások eredményei a kistérségi szint ellentmondásaira is utalnak, hiszen mind a mai napig nincs tisztázva ennek a szintnek a funkciója, és - különösen az országos területi politika szintjén - mủködőképességük sem átlátható, sőt 
Tér és Társadalom, 15. 2001. 2. 71-85. p.

hasznosságuk is sok esetben megkérdöjelezhetö. Mindez abból a sok ellentmondásból adódik, ami a megalakulásukat, átalakulásukat végig kíséri, és ahogyan mind a mai napig a térlefedettséget kezelik.

A kilencvenes évek első felében a kistérségi társulások megjelenése teljes mértékben szabályozatlan volt, részben az önkormányzati törvény, részben a társulási törvény keretében alakultak meg, mindennemủ addigi területi lehatárolásokat figyelmen kívül hagyva. Pontosabban megfigyelhető, hogy az akkori kistérségi társulások a táji, néprajzi határokat követték leginkább, ez a tény a nevükben is tükröződik (Cserehát Településszövetség, Ormánság, Szigetközi Önkormányzatok Szövetsége).

1993-ban bár történt a KSH részéröl egy unn. kistérségi lehatárolás, de ez nem jelentett semmiféle pressziót az 1993-tól megalakuló kistérségek számára.

Az 1996-tól, a területfejlesztési törvény életbe lépésével egy újabb alakulási hullám kezdődött, és most már az új törvény szellemében alakultak meg vagy alakultak újjá a kistérségek, és korábban múködő vagy új szövetségek tagjaivá váltak azok a települések, amelyek korábban még nem tartoztak kistérségi szövetségbe.

A Területfejlesztésről és területrendezésről szóló 1996. évi XXI. törvény III. fejezetében a "területfejlesztést és területrendezést ellátó területi szervek” között szerepel a területfejlesztési önkormányzati társulás, ami a korábban elindult kistérségi szerveződések területfejlesztési törvényben legalizált jogi szervezeti formája. A törvény nem kötelezö jelleggel rendelkezik e jogi személyiséggel rendelkezó társulások létrehozásáról, de a megyei területfejlesztési tanácsok tagjai között a területfejlesztési önkormányzati társulások képviselői jelen vannak, s ezen keresztül nyernek a települések érdekképviseletet. Ezért nevezhetjük a területfejlesztési törvény elfogadását a kistérségi szerveződések mérföldkövének. A törvény tehát felgyorsította a településeknek területfejlesztési társulásokba való belépését, sok esetben létrejöttek a statisztikai kistérség határait lefedő önkormányzati társulások, föleg azokban a megyékben, ahol korábban kistérségi szervezödések nem voltak, vagy ha meg is alakultak, müködésük formális volt (Vas megye).

Tehát 1996-tól jelen voltak a területfejlesztés területén a kilencvenes évek első felében megalakult, legkevésbé sem KSH határos kistérségi szerveződések, melyek sok esetben éppen a vonzáskörzet központját, a várost hagyták ki szervezetükből (ZalaKar, SZÖSZ), viszont ezek azok az önkormányzatí társulások, amelyek már többnyire rendelkeznek a müködőképesség jeleivel. Ezek a kistérségi szerveződések már az 1996. évi XXI. törvény előtt elkezdték müködésüket, eredményeket értek el, elkészíttették fejlesztési koncepciójukat, sőt irodát tudtak müködtetni, valamint átalakulásukkal eleget tettek a törvény szellemének.

Azaz a túlélés lehetséges útjai:

- átalakultak a 1996. évi XXI. törvénynek megfelelően önkormányzati területfejlesztési társulási formára, belépési szándék esetén a térség városát, vagy más belépés szándékával jelentkező települést felvettek a tagjaik sorába, 
s ha statisztikai vonzáskörzetenként több ilyen müködöképes társulás létezett, akkor képviseletüket a területfejlesztési tanácsban rotációs módon oldották meg a területfejlesztési törvény módosításáig;

- a KSH körzet alapján alakították meg a törvényi elöírásoknak megfelelö önkormányzati területfejlesztési társulást, melynek tagjaivá váltak a korábbi társulás települései is, így mintegy kettős tagságot vállaltak;

- KSH körzet határosan megalakították a társulást, s ezzel a korábbi társulásuk megszünt.

Az előzőek azt bizonyítják, hogy ma egymás mellett párhuzamosan léteznek az átalakult és az 1996 után megalakult kistérségi társulások.

Míg az előbbiek elsősorban funkcionális kistérségek, melyek nem KSH határosak, a második csoportba a törvény által presszionált, sok esetben csak formálisan müködő, de az elfogadott területi szintnek megfelelő társulások tartoznak.

1998/99. év fordulóján kezdődött a SAPARD programra való felkészülés, melynek a kistérségek részéröl az első fázisa a vidékfejlesztési program elkészítésére benyújtandó pályázat volt. Ekkor kellett dönteni a több kistérségi társulási tagsággal rendelkező településeknek, hogy hova kötelezik el magukat, mert csak egy kistérségi társulás pályázatában szerepelhettek. Ezzel a pályázati kiírással a kistérségi társulások diszjunkt térlefedésére történt kísérlet.

Tehát addig, amíg az Országos Területfejlesztési Koncepció a kistérségben, a statisztikai vonzáskörzetben, azaz a KSH kistérségben szabta meg a területfejlesztés legkisebb egységét, és a beavatkozási területek is erre a térségi szintre definiálódtak, addig a SAPARD program a funkcionális kistérségekre épít, hiszen elsősorban a már müködőképességüket bizonyítani tudó, pályázatokat levezényelni képes kistérségek kerültek ki nyertesként a SAPARD pályázat első fordulójából, de éppen az egymást lefedö térségi társulások kiküszöbölése végett ezek sem egyeznek meg minden esetben a korábbi funkcionális kistérségekkel.

Jelenleg tehát nagy káosz uralkodik a kistérségi szint körül, de nemcsak a térlefedettséget illetően, hanem a funkcionális formák és a müködőképesség körül is. Ez az a szint, melynek mindeddig központi forrás nem jutott, a tagönkormányzatok által összeadott tagdij minimális, az a formális müködéshez is kevés, abból még projektekre történó pályázatok esetében az önrészre sem futja. Müködésük minden esetben a perszonális tényezőktől függ, azoktól az elkötelezett személyektöl, akik képesek a lelkesedésükkel a lehetetlennek tünő feladatokat és kihívásokat is kezelni.

El kellene végre dönteni, hogy milyen szerepet akarunk betöltetni a kistérségekkel, marad-e mint területfejlesztési szint, s akkor ez milyen kötelezettségekkel és jogokkal párosul, vagy megmarad alulról építkező területfejlesztési civil szervezetnek, de ebben az esetben különbözö erösségü szervezetek fogják kitölteni a teret, melyek közül többen továbbra is a formális müködés jegyeit mutatják, míg lesznek olyanok, melyek képesek lesznek forrásokhoz, sőt EU-s forrásokhoz jutni. 
Az elmúlt évtizedekben minisztériumi szinten gazdátlannak bizonyult ez a szint, ténylegesen valódi helyi, alulról építkező szint volt, addig mára a „SAPARD kistérségek"-ben az FVM, a területfejlesztési társulásokban (amennyiben ezek KSH kistérség határosak) a Miniszterelnöki Hivatal finanszírozza kistérségi megbízottját (meg kell jegyezni, hogy ez a két kistérség földrajzilag sok esetben egybeesik, ha nem, akkor a területfejlesztési társulás menedzsere továbbra sem jut semmilyen központi forráshoz). Továbbá szerencsésnek mondható, ha e két kistérségi felelös között jó a kapcsolat. Újabban a regionális fejlesztési tanács, illetve annak munkaszervezete, az ügynökség is mintha felfedezte volna a kistérségi szintet, sokkal inkább partnerként kezeli, $\mathrm{s}$ a korábbi évekhez képest szorosabb kapcsolatot kívån kialakítani vele. Csakhogy ez a kistérség (valamely központi szervezet által finanszírozott) már nem lesz ugyanaz, mint a kilencvenes évtized kistérsége, aminek a nagyszerüsége, eredményei az akarattal magyarázhatók és az alulról építkezésben keresendők. Félő, hogy éppen ettől, a helyi döntési kompetenciától fosztják meg a mai kistérségi szerveződéseket, $\mathrm{s}$ ebben az esetben már elveszti eddigi erényét, $\mathrm{s}$ a helyi kezdeményezések helyett végrehajtó intézménnyé válik, $\mathrm{s}$ müködésében éppen az alulról építkezés nem fog érvényesülni. Ebben a pillanatban az EU konformitás, azaz az alulról építkezö vidékfejlesztés újra kénytelen lesz keresni a helyét, különösen azért, mert a LEADER programok elnyeréséhez az innovatív, aktív helyi civil csoportokra van szükség.

Valójában megfogalmazódott az a kérdés is, hogy milyen feladatok is hárultak ezekre a szerveződésekre, ezek mennyire kötelező, vagy mennyire önkéntes feladatok. A kutatások ezekre a kérdésekre is választ adtak.

A kistérségi szint feladata, hogy a megyénél kisebb területi egységben a gazdaság és a társadalom térszemléletü fejlesztése történjen meg úgy, hogy az adott térség fejlődése a térség gazdasági és társadalmi szereplöinek érdekképviseletére, érdekfelismerésére és az önmozgására építsen. E szemlélet alapján a térség fejlesztése a helyi gazdaság és társadalom ügye, akik a fejlödést akadályozó problémák és a fejlesztési lehetőségek felismerése alapján összehangolt akciókba kezdenek. Ez az együttműködés önkéntes, jó alapot szolgáltat hozzá a gazdaságföldrajzi-kulturális összetartozás érzése, a hasonló helyzetértékelés és a kapcsolatok közelsége, személyessége.

A kistérségi társulások differenciált müködése során a társulások feladatai is bővültek, a közös érdekképviseleten túl az integrált vidékfejlesztés feladatai váltak alapvetőkké, de az EU-s csatlakozás közeledtével egyre nagyobb szerepet kell, hogy betöltsön az EU-s források megszerzésének feladata, illetve a projekt megvalósítás EU konform gyakorlatának az elsajátítása.

A kérdés, hogy ez az átpolitizált, de nem egységes szint meg tud-e felelni a kívánalmaknak, melyik fajta kistérség kap megerösített funkciót, s hogyan tud betagozódni a magyar és az EU-s területfejlesztés intézményrendszerébe. Tény, hogy a kilencvenes évek végére a magyar regionális és agrárpolitikán belül is felerösödött a vidékpolitika, mely a magyar területi politika EU konformitásával is magyarázható, s ehhez járult még hozzá az utóbbi években a SAPARD elócsatlakozási alapra vałó felkészülés folyamata is. Mindezzel egyidőben 
Szörényiné Kukorelli Irén: Vidékkutatás előzményekkel és tényekkel.

Tér és Társadalom, 15. 2001. 2. 71-85. $p$.

minisztériumi szinten egy tárcához került a területfejlesztés és az agrárium, mely ugyancsak a vidékfejlesztés pozícióját erősítette.

\section{$A$ vidékkutatás ủj irảnyai és perspektívái}

Az elmúlt két-három évben intézetünkben a vidékkel kapcsolatos kutatási témák tovább sokasodtak, de nemcsak mennyiségében, hanem minőségében is változtak. A vidék funkciója a környezet minőségének megörzésére, a környezet-tudat erösítésére irányítja a figyelmet, azaz nemcsak a környezettudományban jártas szakembereknek, hanem a területfejlesztéssel foglalkozó közgazdászoknak, geográfusoknak, szociológusoknak is a környezet-orientált vidékfejlesztést kell fókuszba állítani. Minden területfejlesztési dokumentumnak meg kell találni az egyensúlyt a gazdaság fejlesztése és a környezet megóvása között. Ebben az esetben teljesülhet a vidékfejlesztés feladata és folyamata, mely a következö meghatározással írható körül: A fenntartott és fenntartható gazdasági, társadalmi, kulturális, politikai és környezeti változások egy olyan szándékosan megtervezett folyamata, mely a helyi lakosság életminöségének javitásához járul hozzá.

Jelenleg intézetünkben két transznacionális vidékfejlesztési projekt bonyolódik az EU finanszírozásán belül, melyek eredményeiröl csak a program befejezése után tudunk beszámolni. Az E.D.E.N. projekt a vidéki turizmus fejlesztés és a környezetállapot között keresi az optimális egyensúlyt a helyi konfliktuskezelésen keresztül, s kíván forgatókönyvszerủen mintát adni nem csak a részt vevö országok, hanem valamennyi európai ország számára is.

Intézetünk partnerként vesz rész egy Leonardo projektben, az ún. EURACADEMY programban, mely a fenntartható vidékfejlesztésnek a képzési anyagát készíti el, s teszi hozzáférhetővé a virtuális térben az érdeklődők számára; a programban hat ország vidékfejlesztö szakemberei vesznek részt.

További kutatási projektek, tervek, beadott pályázatok szerepelnek a vidékfejlesztési kutatási témák sorában, melyek mind itthon, mind a nemzetközi szintéren a fenntartható vidékfejlesztés eszközeit kutatják.

Intézetünk vidékkutatással foglalkozó múhelye azt szolgálja, hogy a vidéki térségek ne csak kiegészítỏ szerepet kapjanak a fejlesztés-orientált területeken és folyamatokban, hanem váljanak látványos gazdasági- és élettérré saját értékeik felhasználásával és jövöképük megvalósitásával.

\section{Irodalom}

Lados M. (témavezető) (2000) A jövedelmek alakulása a vidéki térségekben. (Kutatási részjelentés) MTA RKK Nyugat-magyarországi Tudományos Intézet Kozleményei 122. Györ, MTA RKK NYUTI.

Rechnitzer J. (szerk.) (1988) A Rábaköz térszerkezete. Csorna-Kapuvár, MTA RKK Észak-Dunántúli Osztály.

Rechnitzer J.-Szörényiné Kukorelli I. (1994) Győr-Moson-Sopron megye térszerkezete. - Comitatus. 11-12. 73-76. o.

Szorényiné Kukorelli I. (témavezetö) (1994a) Megújitási lehetöségek, térségfejlesztési irányok a Muramenti Nemzetiségi Társulás településeiben I.-II. Kutatási jelentés. Győr, MTA RKK EDO. 
Szörényiné Kukorelli I. (1994b) A régióanalízis eredményeire alapozott térségfejlesztés programja. Szörényiné Kukorelli I. (szerk.) Megújitási lehetőségek, térségfejlesztési irányok a Muramenti Nemzetiségi Térségfejlesztési Társulás településeiben II. Györ, MTA Észak-Dunántúli Osztály.

Szörényiné Kukorelli I. (szerk.) (1995a) A térségfejlesztés társadalmi-gazdasági feltételei Rábcatorok településeiben. MTA RKK NYUTI Közleményei 5/I. Győr, MTA RKK NYUTI.

Szörényiné Kukorelli I. (szerk.) (1995b) A térségfejlesztés stratégiája Rábcatorok településeiben. MTA RKK NYUTI Kozleményei 5/1I. Györ, MTA RKK NYUTI.

Szörényiné Kukorelli 1.(1997a) Fejlesztési koncepciók a kistérségek számára (Összegzés) - Tér és Társadalom. 3. 93-99. o.

Szơrényiné Kukorelli I. (1997b) A kistérségek gazdasági és társadalmi jellemzői és trendjei ÉszakDunántúlon. - Tér és Társadalom. 1. 147-181. o.

Szorrényiné Kukorelli I. (témavezető) (1998) A kistérségi területfejlesztési társulások hatékonyabb müködéséért Györ-Moson-Sopron megyében. MTA RKK NYUTI Közleményei 84. Györ, MTA RKK NYUTI.

Szörényiné Kukorelli I. (témavezető) (1999a) A Muramenti Nemzetiségi Területfejlesztési Társulás vidékfejlesztési stratégiai programja. MTA RKK NYUTI Közleményei 104. Györ, MTA RKK NYUTI.

Szörényiné Kukorelli 1. (témavezetô) (1999b) A térségmenedzserek szerepe a kistérségi szervezödések müködöképességében. (OFA) MTA RKK NYUTI Kozleményei 92. Györ, MTA RKK NYUTI.

Szörényiné Kukorelli I. (témavezetö) (1999c) Alulról épitkezö vidékfejlesztés feltételrendszere és intézményrendszere Magyarországon II/A. A partnerség megjelenése a vidékfejlesztés intézményrendszerében, különös tekintettel a civil szervezetek reprezentációjára. MTA RKK NYUTI Közlemények 102. Györ, MTA RKK NYUTI.

Szörényiné Kukorelli 1. (1999d) A kistérségi szervezödések finanszírozási lehetőségei I. - Comitatus. 12. Szörényiné Kukorelli 1. (2000a) A kistérségi szervezödések finanszírozási lehetöségei Il. - Comitatus. 1. Szörényiné Kukorelli I. (2000b) A kistérségi szervezödések életképessége, a térségmenedzserek szerepe - Horváth Gy.-Rechnitzer J. (szerk.) Magyarország területi szerkezete és folyamatai az ezredfordulón. Pécs, MTA RKK. 218-234. o.

Szörényiné Kukorelli I. (2000c) Vállalkozások és a nơi szerepek az osztrák határ menti falvakban. Szónokyné Ancsin G. (szerk.) Határok és régiók. Szeged, JATEPress. 271-281. o.

\section{RESEARCH OF RURAL AREAS WITH PRELIMINARIES AND FACTS IRÉN SZÖRÉNYINÉ KUKORELLI}

Researches of rural areas were always a dominant part of the spatial process researches during the 15 years existence of the West Hungarian Research Institute. Our institute concentrated in the last one and a half-decade to the following issues:

- What were the impacts of process started with the transformation of political and socioeconomic system on the peripheral regions and rural areas?

- What were the impacts of the regional policy of the European Union?

- To what extent did the establishment of the new institutional system and instruments of regional development contribute to the restructuring of rural spaces?

- To what extent were the rural areas differentiated?

- Was there any change in their functions?

Summary of the results of researches in the fields of the change in the spatial structures, the formation and operable of small regions and the rural economy and incomes give answer for us to the above questions. 